\title{
Resilience of family caregivers of children and adolescents in treatment of neoplasms and associated factors
}

\author{
Resiliência de cuidadores familiares de crianças e adolescentes em tratamento de neoplasias e fatores associados \\ Resiliencia de cuidadores familiares de niños y adolescentes en tratamiento de neoplasias y factores relacionados
}

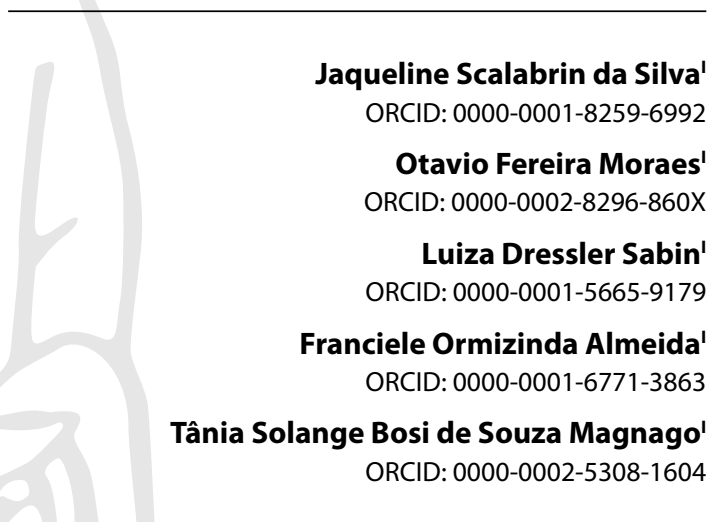

'Universidade Federal de Santa Maria. Santa Maria, Rio Grande do Sul, Brazil.

How to cite this article:

Silva JS, Moraes OF, Sabin LD, Almeida FO, Magnago TSBS. Resilience of family caregivers of children and adolescents in treatment of neoplasms and associated factors. Rev Bras Enferm. 2021;74(6):e20190388. https://doi.org/10.1590/0034-7167-2019-0388

Corresponding author:

Tânia Solange Bosi de Souza Magnago E-mail:magnago.tania@gmail.com

EDITOR IN CHIEF: Dulce Barbosa ASSOCIATE EDITOR: Cristina Parada

Submission: 08-16-2019

Approval: 05-27-2021

\begin{abstract}
Objectives: analyze the level of resilience of family caregivers of children and adolescents hospitalized for cancer treatment and associated factors. Methods: cross-sectional study, carried out in 2018, with 62 family caregivers in a university hospital in the state of Rio Grande do Sul, Brazil. The instruments CDRisc-10-Br, SRQ20, PSS-14 and WHOQOL-Bref were used to measure resilience, minor psychological disorders, stress, and quality of life, respectively. Inferential statistics were used. Results: female caregivers, married, with one child and who practice some predominated religion. They were classified as having a moderate level of resilience (48.4\%); with suspicion for minor psychological disorders (45\%) and high level of stress (41\%). In terms of quality of life, they were satisfied in the Physical, Psychological and Social Relations domains; and dissatisfied in the Environment domain. Conclusions: there were direct weak to moderate correlations between the level of resilience and quality of life and inversely with stress and minor psychological disorders.

Descriptors: Resilience Psychological; Nursing; Occupational Health; Neoplasms; Caregivers.
\end{abstract}

\section{RESUMO}

Objetivos: analisar o nível de resiliência de cuidadores familiares de crianças e adolescentes hospitalizados para tratamento oncológico e os fatores associados. Métodos: estudo transversal, realizado em 2018, com 62 cuidadores familiares em um hospital universitário do estado do Rio Grande do Sul, Brasil. Utilizaram-se os instrumentos CDRisc-10-Br, SRQ20, PSS-14 e WHOQOL-Bref para mensurar a resiliência, distúrbios psíquicos menores, estresse e qualidade de vida, respectivamente. Empregou-se estatística inferencial. Resultados: predominaram cuidadores do sexo feminino, casados, com um filho e que praticam alguma religião. Foram classificados em nível moderado de resiliência (48,4\%); com suspeição para distúrbios psíquicos menores (45\%) e alto nível de estresse (41\%). Na qualidade de vida, estavam satisfeitos nos domínios Físico, Psicológico e Relações sociais; e insatisfeitos no domínio Meio ambiente. Conclusões: evidenciaram-se correlações fraca a moderada de forma direta entre nível de resiliência e qualidade de vida e de forma inversa com estresse e distúrbios psíquicos menores.

Descritores: Resiliência Psicológica; Enfermagem; Saúde do Trabalhador; Neoplasias; Cuidadores.

\section{RESUMEN}

Objetivos: analizar nivel de resiliencia de cuidadores familiares de niños y adolescentes hospitalizados para tratamiento oncológico y factores relacionados. Métodos: estudio transversal, realizado en 2018, con 62 cuidadores familiares en un hospital universitario del estado del Rio Grande do Sul, Brasil. Utilizaron los instrumentos CDRisc-10-Br, SRQ20, PSS-14 yWHOQOLBref para mensurar la resiliencia, disturbios psíquicos menores, estrés y calidad de vida, respectivamente. Empleó estadística inferencial. Resultados: predominaron cuidadores del sexo femenino, casados, con un hijo y que practican alguna religión. Fueron clasificados en nivel moderado de resiliencia $(48,4 \%)$; con sospecha para disturbios psíquicos menores (45\%) y alto nivel de estrés (41\%). En la calidad de vida, estaban satisfechos en los dominios Físico, Psicológico y Relaciones sociales; e insatisfechos en el dominio Medio ambiente. Conclusiones: evidenciaron correlaciones débil a moderada de manera directa entre nivel de resiliencia y calidad de vida y de manera inversa con estrés y disturbios psíquicos menores. Descriptores: Resiliencia Psicológica; Enfermería; Salud Laboral; Neoplasias; Cuidadores. 


\section{INTRODUCTION}

Cancer is considered a public health problem, especially in developing countries, due to its epidemiological, social, and economic magnitude. It is one of the main causes of illness and death in the world population(1). Among the types of cancer, there is the juvenile one, which is considered rare (2\% to $3 \%$ ) when compared to those that affect adults. For this biennium, approximately 12,500 new cases of cancer are estimated in children and adolescents (from 0 to 19 years of age) ${ }^{(1)}$. The discovery of childhood cancer has an impacting meaning, as it affects expectations about the future of the child or adolescent. In other words, the presence of the disease does not match the image of vitality and development linked to childhood and adolescence. Cancer is a challenge for everyone, it has the social stigma of an incurable, painful and fatal disease, which can shake and disrupt the family, producing feelings of fear and emotional conflicts ${ }^{(24)}$.

In this sense, it is important to research the resilience of family caregivers as a possibility for reflection and expansion of the way of perceiving care. Resilience embodies the personal qualities that allow an individual to thrive in the face of adversity. It is understood as the set of dynamic, psychic and social processes that refer to the ability of human beings to overcome stressful events in life, as is the case of people who face cancer, whether patients or family members ${ }^{(5-7)}$.

This relationship between the dimensions of care and the impact generated on the family and on the family caregiver's life can lead to overload, stress and anxiety, with consequent changes in quality of life ${ }^{(8)}$. In this study, the "family caregiver" was considered to be the one who follows the child/adolescent's disease process and treatment. In the literature, they are also responsible for assisting in tasks that require direct or indirect care, facing challenges in decision-making; often, needing to reorient their personal expectations and projections $s^{(9)}$.

Cancer can bring both psychic and physical changes in family caregivers and destabilize the lives of those involved during therapy. Overload can generate stress and anxiety in response to the demands experienced in caring for a cancer patient. On the other hand, it is possible to see that lower levels of psychological suffering are associated with higher levels of resilience. Thus, from this resilient perspective, it is possible to create possibilities and develop such behavior ${ }^{(10-14)}$.

Faced with the question about the impact on the multiple relationships of the family that has a cancer patient, on the one hand, few productions are evidenced regarding family caregivers of children and adolescents undergoing cancer treatment and the repercussions on their life, specifically focusing on resilience. On the other hand, several studies focus on the impact of cancer on the quality of life of family caregivers, showing that damage can affect both the caregiver and the family as a whole $e^{(8,15)}$.

In this context, it is important to carry out studies with family caregivers, who often give up their own life to accompany the child or adolescent during hospitalization. Also, knowing them, as well as their health status, can help them to strengthen their resilience to face this difficult time. Resilience is an ongoing process that tones up the potential of individuals. Thus, the analysis of resilience and associated factors in this population brings contributions to health professionals. This can provide leverage to strategies to minimize unnecessary stressors and contribute to improving the quality of life of family caregivers, as resilience can be considered a component of long-term well-being ${ }^{(16-17)}$.

\section{OBJECTIVES}

To analyze the level of resilience of family caregivers of children and adolescents hospitalized for cancer treatment and associated factors.

\section{METHODS}

\section{Ethical aspects}

The study was submitted and approved by the Ethics and Research Committee of the Federal University of Santa Maria (UFSM). The project was prepared in accordance with Resolution No. 466/2012 of the National Health Council, which establishes parameters for research involving human beings. Participation was voluntary, after explanation of the research objectives. Upon accepting the participation, it was requested to sign the Free and Informed Consent Form (ICF), in duplicate, one with the participant and the other with the researcher. Formal authorization to use the CDRisc-10 instrument was obtained ${ }^{(18)}$.

\section{Study design, period and place and period}

This is a cross-sectional epidemiological study, with writing guided by the STROBE tool. Data collection was carried out from February to September 2018, in the pediatric oncology inpatient unit of a public and teaching hospital in the interior of the state of Rio Grande do Sul (RS). This is a large hospital and a reference in high and medium complexity for 43 municipalities in the central-west region of the state.

\section{Population, inclusion, and exclusion criteria}

A census was carried out with all family caregivers of children and adolescents who were hospitalized and who met the inclusion criteria: being a caregiver of the child or adolescent during hospitalization and being over 18 years of age. The exclusion criterion was caregivers who presented a cognitive deficit (identified by the health team) to the point of impairing their understanding of reality and understanding of the research instruments.

Considering an estimate of hospitalizations in the period $(\mathrm{N}$ $=58$ ), a proportion of $50 \%$, a sampling error of $5 \%$ and a loss of $15 \%$, the minimum sample required was 60 family caregivers. They were voluntarily included in the survey as they arrived for hospitalization. For data collection, a period of adaptation to the new context experienced ( 20 to 30 days) was awaited, so that they had a better understanding of the new reality in which they were inserted. All were informal caregivers, being able to be mother, father, stepfather, partner, aunt, sister, or grandparents.

\section{Study protocol}

The research instrument consisted of variables such as: gender (female/male), family caregiver (mother/father/brother/uncle/ grandparents), age (completed years/age group), education (elementary/high school/graduate/post-graduate), marital status 
(single/married/stable union), number of children, practice a religion (no/yes), region of residence (urban/rural), previous illness (no/yes), use of medications (no/yes), yes), physical activity (no/yes), leisure activity (no/yes), if you were working on finding the diagnosis (no/ yes), if you continued working (no/yes). The instruments Resilience Scale (CD-RISC-10-Br) ${ }^{(18)}$, Self-Reporting Questionnaire-20 (SRQ-20) ${ }^{(19)}$, World Health Organization Quality of Life instrument (WHOQOL bref $)^{(20)}$ and Perceived Stress Scale were used (PSS-14) ${ }^{(21)}$.

The CD-RISC-10-Br, adapted to the Brazilian context, seeks to assess the individual's level of resilience. It consists of ten items, in Likert format, ranging from 0 (never true) to 4 (always true) ${ }^{(18)}$. The Self-Reporting Questionnaire-20 (SRQ-20) is used to investigate the presence of minor psychological disorders (MPD), validated in Brazil by Mari and Williams in 1986. The Brazilian version has 20 dichotomous yes and no questions ${ }^{(19)}$. As for the WHOQOL bref, it is a scale aimed at investigating the quality of life, comprising 26 questions. The answers to the WHOQOL-bref questions are given on a Likert-type scale, ranging from 1 to 5 , with a scale of intensity (from nothing to extremely), capacity (from nothing to completely), frequency (from never to always) and evaluation (from very dissatisfied to very satisfied; very bad to very good) and is divided into four domains: Physical, Psychological, Social relations and Environment ${ }^{(20)}$. Finally, PSS-14 was adapted to the Brazilian context and contains 14 questions, ranging on a Likert scale from 0 (never) to 4 (always) ${ }^{(21)}$.

\section{Analysis of results and statistics}

Double data entry was performed independently, that is, two typists, previously trained, were responsible for the task. Typing errors and inconsistencies were checked and corrected in the review process, using the "validate" of the Epi-Info" software (version 6.4). Afterwards, data analysis was performed using the SPSS $^{\circ}$ program (Statistical Package for the Social Sciences, SPSS Inc, Chicago), version 18.0 for Windows.

Data normality was assessed using the Kolmogorov-Smirnov test. Categorical variables were evaluated using absolute $(\mathrm{N})$ and relative (\%) frequencies; and quantitative variables were calculated through mean, median, standard deviation, minimum, maximum, according to the normality or not of the data. Also, bivariate analyzes and Spearmann correlations were performed. In the bivariate analyses, Pearson's chisquare test was used with analysis of adjusted standardized residuals. For the correlations, the following points were adopted: $r$ from 0.10 to 0.39 as a weak dependence between the variables; from 0.40 to 0.69 as moderate; and from 0.70 to 1.00 as a strong correlation. In all analyses, a significance level of $5 \%(p<0.05)$ was used ${ }^{(22)}$.

For the CD-RISC-10-Br, the score from 0 to 24 refers to a low level of resilience; from 25 to 74, moderate level; and from 75 to 100 , a high level of resilience ${ }^{(18)}$. In the Self-Reporting Questionnaire-20 (SRQ-20), a score of seven or more positive answers was considered suspicious for MPDs (minor psychological disorders ${ }^{(19)}$. In the WHOQOL-bref, the score obtained for each statement is given by the total score of the attitude of each respondent. In each facet, just add the interview values (from 1 to 5) and divide by the number of participants: an average is then obtained where the result will be from 1 to 5 , so that the higher the As a result, the quality of life will be better ${ }^{(20)}$. In PSS-14, scores ranging from 22 to 27 were considered as having low perceived stress; moderate, from 28 to 29; and high perceived stress, from 30 to 43 points ${ }^{(21)}$.

\section{RESULTS}

In the collection period, 58 children or adolescents were hospitalized for oncological treatment. Of these 3 did not stay a sufficient period of time (more than 20 days to meet inclusion criteria; and a family caregiver who refused participation.) Of the 54 hospitalized patients eligible of the study, 62 family caregivers participated in eight situations, included more than one family caregiver per child or adolescent.

The highest percentage of family caregivers was female (80.6\%), predominantly mothers, aged from 37 to 66 years (54.8\%), had completed high school (35.5\%), were married/union stable (69.4\%), had a child (32.3\%) and practiced some religion (77.4\%). They had no previous disease (79\%), did not use medication (77.4\%), did not practice physical activity before discovering the disease (64.5\%); however, among those who practiced, $32.3 \%$ stopped practicing. As for leisure activities, $67.7 \%$ reported having some activity. Regarding the employment situation, $66.1 \%$ worked before discovering childhood cancer in the family. At the time of collection, $57.4 \%$ of them did not work to dedicate themselves to care. In Table 1, the absolute and relative frequencies of the level of resilience, suspicion of minor psychological disorders (MPDs), perceived stress and domains of quality of life of family caregivers are described.

Table 1 - Distribution of family caregivers of children and adolescents undergoing cancer treatment according to level of resilience, suspicion for minor psychological disorders, perceived stress, and quality of life domains, Santa Maria, Rio Grande do Sul, Brazil, 2018, $(\mathrm{N}=62)$

\begin{tabular}{|c|c|c|}
\hline Health variables & $\mathbf{n}$ & $\%$ \\
\hline \multicolumn{3}{|l|}{ Resilience } \\
\hline Low level & 16 & 25.8 \\
\hline Moderate level & 30 & 48.4 \\
\hline High level & 16 & 25.8 \\
\hline \multicolumn{3}{|l|}{ MDP suspicion } \\
\hline Yes & 27 & 45 \\
\hline No & 33 & 55 \\
\hline \multicolumn{3}{|l|}{ Perceived stress } \\
\hline Low level & 18 & 29.5 \\
\hline Moderate level & 18 & 29.5 \\
\hline High level & 25 & 41.0 \\
\hline \multicolumn{3}{|l|}{ QL Domains } \\
\hline \multicolumn{3}{|l|}{ Physical Domain } \\
\hline Dissatisfied & 20 & 32.3 \\
\hline Satisfied & 42 & 67.7 \\
\hline \multicolumn{3}{|c|}{ Psychological Domain } \\
\hline Dissatisfied & 23 & 37.1 \\
\hline Satisfied & 39 & 62.9 \\
\hline \multicolumn{3}{|c|}{ Social Relations Domain } \\
\hline Dissatisfied & 24 & 38.7 \\
\hline Satisfied & 38 & 61.3 \\
\hline \multicolumn{3}{|c|}{ Environment Domain } \\
\hline Dissatisfied & 47 & 75.8 \\
\hline Satisfied & 15 & 24.2 \\
\hline
\end{tabular}

A moderate level of resilience prevailed for $48.4 \%(\mathrm{~N}=30)$ of family caregivers; $45 \%(\mathrm{~N}=27)$ were suspicious for MPD, and $41 \%(\mathrm{~N}=25)$ were under a high level of stress during the care 
process and hospitalization of the child or adolescent undergoing cancer treatment. In the analysis of quality of life (QL), the highest percentage of family caregivers reported being satisfied in the Physical domains (67.7\%; $N=42)$; Psychological $(62.9 \% ; N=39)$ and Social relations $(61.3 \% ; \mathrm{N}=38)$. They were dissatisfied in the Environment domain $(75.8 \% ; \mathrm{N}=47)$. Table 2 shows the relationship between levels of resilience and sociodemographic data.

Table 2 - Distribution of family caregivers of children and adolescents undergoing cancer treatment according to level of resilience and sociodemographic factors, Santa Maria, Rio Grande do Sul, Brazil, 2018, (N = 62)

\begin{tabular}{|c|c|c|c|c|c|c|c|}
\hline \multirow[t]{2}{*}{$\begin{array}{l}\text { Sociodemographic } \\
\text { variables }\end{array}$} & \multicolumn{2}{|c|}{ Low } & \multicolumn{2}{|c|}{$\begin{array}{l}\text { Resilience } \\
\text { Moderate }\end{array}$} & \multicolumn{2}{|c|}{ High } & \multirow[t]{2}{*}{$p^{*}$} \\
\hline & $\mathbf{n}$ & $\%$ & $\mathbf{n}$ & $\%$ & $\mathbf{n}$ & $\%$ & \\
\hline Sex & & & & & & & $0.183^{* *}$ \\
\hline Female & 14 & 28.0 & 25 & 50.0 & 11 & 22.0 & \\
\hline Male & 2 & 16.7 & 5 & 41.7 & 5 & 41.7 & \\
\hline Age group & & & & & & & 0.713 \\
\hline 20 to 36 years & 7 & 25.0 & 15 & 53.6 & 6 & 21.4 & \\
\hline 37 to 66 years old & 9 & 26.5 & 15 & 44.1 & 10 & 29.4 & \\
\hline Educational level & & & & & & & $0.255^{* *}$ \\
\hline Elementary incomplete & 6 & 33.3 & 6 & 33.3 & 6 & 33.3 & \\
\hline Complete Elementary & 2 & 45.5 & 6 & 54.5 & - & - & \\
\hline Incomplete high school & - & - & 2 & 66.7 & 1 & 33.3 & \\
\hline Complete high school & 4 & 18.2 & 11 & 50 & 7 & 31.8 & \\
\hline Incomplete graduation & 1 & 33.3 & 1 & 33.3 & 1 & 33.3 & \\
\hline Full graduation & - & - & 3 & 75.0 & 1 & 25.0 & \\
\hline Complete postgraduate & - & - & 1 & 100 & - & - & \\
\hline Marital status & & & & & & & $0.057^{* *}$ \\
\hline Single/no partner & 6 & 31.6 & 12 & 63.2 & 1 & 5.3 & \\
\hline Married/Stable Marriage & 10 & 23.3 & 18 & 41.9 & 15 & 34.9 & \\
\hline Number of children & & & & & & & $0.532^{* *}$ \\
\hline 0 or 1 & 7 & 31.8 & 11 & 50.0 & 4 & 18.2 & \\
\hline 2 or more & 9 & 22.5 & 19 & 47.5 & 12 & 30.0 & \\
\hline practice some religion & & & & & & & $0.208^{* *}$ \\
\hline No & 4 & 28.6 & 9 & 64.3 & 1 & 7.1 & \\
\hline Yes & 12 & 25.0 & 21 & 43.8 & 15 & 31.3 & \\
\hline Region of residence & & & & & & & 0.985 \\
\hline Urban & 11 & 26.2 & 20 & 47.6 & 11 & 26.2 & \\
\hline Rural & 5 & 25.0 & 10 & 50.0 & 5 & 25.0 & \\
\hline
\end{tabular}

There was no significant difference between the groups evaluated in terms of levels of resilience and sociodemographic factors ( $p>0.05$ ). In Table 3, the associations between levels of resilience, physical activity and leisure activities of family caregivers are described.

There was no statistical significance between the levels of resilience, physical activity, leisure and working life of family caregivers of children and adolescents hospitalized for cancer treatment $(p>0.05)$. Table 4 shows the relationship between levels of resilience and health variables (MDP, stress and quality of life) of family caregivers.

Family caregivers classified as having a low level of resilience had higher percentages of suspected MPD (44.4\%); those with a high level were classified without suspicion of MPD (36.4\%; $p=$ 0.012 ). As for perceived stress, it was evident that caregivers with a high level of stress had low resilience (44\%), those with a moderate level of stress were moderately resilient (61.1\%), and those with a low level of stress had a high level of resilience (38.9\%; $p=0.020$ ). Also, it was evident that family caregivers dissatisfied with their quality of life in the Environment domain were classified as having resilience at intermediate $(55.3 \%)$ and low $(29.8 \% ; p=0.004)$ levels.
Table 3 - Distribution of family caregivers of children and adolescents undergoing cancer treatment according to level of resilience, physical activity, leisure, and labor variables, Santa Maria, Rio Grande do Sul, Brazil, 2018, (N = 62)

\begin{tabular}{|c|c|c|c|c|c|c|c|}
\hline \multirow{2}{*}{$\begin{array}{l}\text { Physical activity, } \\
\text { leisure, and work } \\
\text { variables }\end{array}$} & \multicolumn{2}{|c|}{ Low } & \multicolumn{2}{|c|}{ Resilience } & \multicolumn{2}{|c|}{ High } & \multirow[t]{2}{*}{$p^{*}$} \\
\hline & $\mathbf{n}$ & $\%$ & $\mathbf{n}$ & $\%$ & $\mathbf{n}$ & $\%$ & \\
\hline Practiced physical activity & & & & & & & $0.066^{* *}$ \\
\hline No & 14 & 35.0 & 18 & 45.0 & 8 & 20.0 & \\
\hline Yes & 2 & 9.1 & 12 & 54.5 & 8 & 36.4 & \\
\hline Continued practicing & & & & & & & $0.750^{* *}$ \\
\hline No & 2 & 10.0 & 10 & 50.0 & 8 & 40.0 & \\
\hline Yes & - & - & 3 & 60.0 & 2 & 40.0 & \\
\hline Partake in leisure activity & & & & & & & $0.156^{* *}$ \\
\hline No & 8 & $40 \%$ & 9 & 45.0 & 3 & 15.0 & \\
\hline Yes & 8 & 19.0 & 21 & 50.0 & 13 & 31.0 & \\
\hline Currently works & & & & & & & $0.175^{* *}$ \\
\hline No & 2 & 34.3 & 14 & 40.0 & 9 & 25.7 & \\
\hline Yes & 4 & 15.4 & 16 & 61.5 & 6 & 23.1 & \\
\hline Continued working & & & & & & & $0.297^{* *}$ \\
\hline No & 9 & 32.1 & 11 & 39.3 & 8 & 28.6 & \\
\hline Yes & 3 & 13.6 & 12 & 54.5 & 7 & 31.8 & \\
\hline
\end{tabular}

Table 4 - Analysis of levels of resilience according to health variables of caregivers of children and adolescents with cancer treatment, Santa Maria, Rio Grande do Sul, Brazil, 2018, (N=62)

\begin{tabular}{|c|c|c|c|c|c|c|c|}
\hline \multirow[t]{2}{*}{ Health variables } & \multicolumn{2}{|c|}{ Low } & \multicolumn{2}{|c|}{ Resilience } & \multicolumn{2}{|c|}{ High } & \multirow[t]{2}{*}{$p^{*}$} \\
\hline & $\mathbf{n}$ & $\%$ & $\mathbf{n}$ & $\%$ & $\mathbf{n}$ & $\%$ & \\
\hline MDP & & & & & & & $0.012^{*}$ \\
\hline No & 4 & 12.1 & 17 & 51.5 & 12 & $36.4^{*}$ & \\
\hline Yes & 12 & $44.4^{*}$ & 11 & 40.7 & 4 & 14.8 & \\
\hline Perceived stress & & & & & & & $0.020^{*}$ \\
\hline Low level & 1 & 5.6 & 10 & 55.6 & 7 & $38.9^{*}$ & \\
\hline Moderate level & 4 & 22.2 & 11 & $61.1^{*}$ & 3 & 16.7 & \\
\hline High level & 11 & $44.0^{*}$ & 8 & 32.0 & 6 & 24.0 & \\
\hline \multicolumn{8}{|l|}{ Quality of life Domains } \\
\hline Physical Domain & & & & & & & $0.491^{*}$ \\
\hline Dissatisfied & 7 & 35.0 & 9 & 45.0 & 4 & 20.0 & \\
\hline Satisfied & 9 & 21.4 & 21 & 50.0 & 12 & 28.6 & \\
\hline Psychological Domain & & & & & & & $0.211^{*}$ \\
\hline Dissatisfied & 7 & 30.4 & 13 & 56.5 & 3 & 13.0 & \\
\hline Satisfied & 9 & 23.1 & 17 & 43.6 & 13 & 33.3 & \\
\hline Social Relations Domain & & & & & & & $0.342^{*}$ \\
\hline Dissatisfied & 8 & 33.3 & 12 & 50.0 & 4 & 16.7 & \\
\hline Satisfied & 8 & 21.1 & 18 & 47.4 & 12 & 31.6 & \\
\hline Environment Domain & & & & & & & $0.004^{*}$ \\
\hline Dissatisfied & 14 & $29.8^{*}$ & 26 & $55.3^{*}$ & 7 & 14.9 & \\
\hline Satisfied & 2 & 13.3 & 4 & 26.7 & 9 & $60.0^{*}$ & \\
\hline
\end{tabular}

Note: * Pearson's chi-square test; ** Pearson's chi-square with correction; $¥$ adjusted standardized residuals; $M P D$ - minor psychological disorders.

Table 5 shows the correlations between resilience, age, length of employment, suspicion of minor psychological disorders, perceived stress, and quality of life domains of family caregivers of children and adolescents undergoing cancer treatment.

Resilience showed moderate negative correlation with MPD ( $r=$ -0.541 ) and weak correlation with perceived stress $(r=-0.371)$, showing that the higher the level of resilience, the lower the scores for suspicion of MPD and perceived stress. Weak to moderate positive correlation was evidenced between the resilience scores and those of the Physical $\mathrm{QL}(r=0.330)$, Psychological $(r=0.392)$, Social relationship $(r=0.351)$ and Environment $(r=0.460)$ domains, as well as with general QoL ( $r$ $=0.372$ ), showing that the higher the level of resilience, the higher the general QL and the higher the QL in each domain. 
Table 5 - Spearmann correlations between resilience, age, length of employment, suspicion of minor psychological disorders, perceived stress, and quality of life domains of family caregivers of children and adolescents undergoing cancer treatment, Santa Maria, Rio Grande do Sul, Brazil, 2018

\begin{tabular}{|c|c|c|c|c|c|c|c|c|c|c|}
\hline Variables & 1 & 2 & 4 & 5 & 6 & 7 & 8 & 9 & 10 & 11 \\
\hline 1. Resilience & 1 & & & & & & & & & \\
\hline 2. Age & .138 & 1 & & & & & & & & \\
\hline 3. MDP & $-.541^{* *}$ & -.110 & 1 & & & & & & & \\
\hline 4. Perceived stress & $-.371^{* *}$ & .037 & $.550^{* *}$ & 1 & & & & & & \\
\hline 5. PhQL & $.330^{* *}$ & .128 & $-.806^{* *}$ & $-.331^{* *}$ & 1 & & & & & \\
\hline 6. PsQL & $.392^{* *}$ & .191 & $-.622^{* *}$ & $-.396^{* *}$ & $.489^{* *}$ & 1 & & & & \\
\hline 7. SRQL & $.351^{* *}$ & .053 & $-.594^{* *}$ & $-.452^{* *}$ & $.444^{* *}$ & $.483^{* *}$ & 1 & & & \\
\hline 8. EQL & $.460^{* *}$ & .137 & $-.517^{* *}$ & $-.307^{*}$ & $.391^{* *}$ & $.468^{* *}$ & $.461^{* *}$ & 1 & & \\
\hline 9. $\mathrm{GQL}^{* * *}$ & .221 & .027 & $-.351^{* *}$ & -.197 & $.377^{* *}$ & $.274^{*}$ & .164 & .229 & 1 & \\
\hline 10. SHQL *** & $.372^{* *}$ & -.006 & $-.486^{* *}$ & -.231 & $.453^{* *}$ & $.442^{* *}$ & $.375^{* *}$ & .133 & $.417^{* *}$ & * 1 \\
\hline
\end{tabular}

MPD-minorpsychological disorders; QL - quality of life; PhQL - Physical QoL;PsQL-Psychological QL;SRQL-Social relationship QV; EQL - Environment QL; GQL - General QL; SHQL-QL Satisfaction with health.

Note: *statistical significance at $0.001 ;{ }^{* *}$ statistical significance at 0.05 . Points: $r$ from 0.10 to 0.39 as weak dependence between variables; 0.40 to 0.69 as moderate; and from 0.70 to 1.00 as a strong correlation (DANCEY, C.; REIDY, J., 2006); *** item referring to questions 1 and 2 of the WHOQOL-Bref.

\section{DISCUSSION}

In this study, female family caregivers predominated (80.6\%), a fact also brought by other authors, with a percentage of $82.5 \%$ to $87.5 \%{ }^{(8,23)}$. The predominance of family caregivers married/in a stable relationship $(69.4 \%)$ was also found in other studies ${ }^{(8,17,24)}$. As for the practice of physical activity, of the $35.5 \%$ who practiced before the disease, $8.1 \%$ continued to practice, corroborating another study that brought a reduction from $30.9 \%$ to $16.7 \%$ in the practice of physical activity ${ }^{(8)}$. It is worth remembering that physical activity increases the level of endorphins, which helps in relaxation, helping the person to remain mentally healthy, face challenges and changes with balance. The percentage of people who left work in this study was $23.5 \%$, confirming other studies that bring an increase in the number of unemployment among caregivers of children and adolescents undergoing cancer treatment from $9.1 \%$ to $59.5 \%{ }^{(8)}$ and percentage of $90 \%$ and $78.5 \%$ of unemployed ${ }^{(24-25)}$.

In the present study, family caregivers predominantly showed a moderate level of resilience (48.4\%). For comparison purposes, a study evaluated the resilience of parents who had undergone cancer treatment for a child and showed that $63 \%(\mathrm{~N}=53)$ of the non-bereaved and 52\% ( $N=11)$ of the bereaved were considered resilient ${ }^{(17)}$. Measuring resilience is a challenge, especially in this population. There are several factors that permeate the lives of family caregivers and that can affect the way they see the situation experienced during the treatment of childhood cancer. However, in this study, it was observed that sociodemographic, work and habits factors do not seem to be significantly associated with a higher or lower level of resilience. Deepening this knowledge is really important.

For example, it is known that support in a religious belief/spirituality is common during times of adversity and proves to be an essential factor. That is, family members look for ways to reduce their suffering through strength and faith. Of the participants in this study, $77.4 \%$ said they practiced a religion, but there was no evidence of an association with a higher level of resilience ( $p>0.05)$.

A study found that family members of cancer patients undergoing chemotherapy and classified as having low resilience were those with a lower level of spirituality ${ }^{(5)}$. Spirituality is not necessarily linked to a religion (set of beliefs and cults; rites and dogmas). It is linked to well-being, knowledge of the human soul and a greater plan. Religiosity, spirituality, and faith can help in the process of developing resilience. They are often associated by people, who seek ways to strengthen this group. They are a mechanism, an important source of support that family caregivers can use to face the difficult reality. Spirituality is also seen as a support, increasing the relationship between hope and coping with childhood cancer by family caregivers ${ }^{(25-28)}$.

Even in the face of difficulties, studies show that the presence of affliction does not exclude the capacity for resilience. Parents of children with cancer can simultaneously report positive and negative psychological results from this experience. Therefore, it is important to promote resilience as a way to improve psychosocial outcomes among parents of children with cancer. For every point of decrease in resilience resources, the chances of negative psychosocial outcomes increase. Resilience scores can be modified with interventions, and this has been associated with better psychosocial outcomes. That is, promoting parental resilience can provide an opportunity to improve family survival after pediatric cancer ${ }^{(17,24)}$.

Resilience is an important concept when working with families, as it emphasizes the potential of the human being, the capacity to give new meaning, even under adverse conditions, such as the case of coping with childhood cancer. This concept can be applicable to the family caregiver in the process of illness and recovery of cancer patients. Being resilient, instead of highlighting family mismatches and failures, helps to highlight their healthy aspects, in which strategies are developed based on subjectivity, experiences and relationships built with other people throughout life. This situation provides greater empowerment to family members, facilitating decision-making, with a focus on positivity ${ }^{(5,10,14)}$.

The need to cope with cancer can bring numerous controversial feelings to family caregivers. Even with the faith, religiosity, spirituality, and social support used for this confrontation, the situation of illness of a child or adolescent due to cancer can bring psychological changes to family caregivers, among which are minor psychological disorders. In this study, $45 \%$ of family caregivers had scores indicating suspicion for MPD, and $44.4 \%$ had a low level of resilience.

There is evidence in the literature that $41 \%$ of family members of adult patients undergoing cancer treatment had symptoms of anxiety and $15.3 \%$ had depressive symptoms ${ }^{(5)}$. In South Korea, $48 \%$ of relatives of cancer patients revealed symptoms of anxiety, and $10.3 \%$ at a severe level ${ }^{(12)}$. Also, higher levels of resilience are associated with lower levels of psychological distress in caregivers of cancer patients in Australia ${ }^{(13)}$. Still, a study that evaluated the burden of caregivers of children with cancer found that $100 \%$ of them had symptoms of anxiety and depression ${ }^{(29)}$.

The hospitalization process can be stressful for both the patient and the family member, interfering with their health ${ }^{(23)}$. The results of this and other studies show the need for a broader look at family caregivers. In this context, $41 \%$ of family caregivers in the present study had a high level of perceived stress. When 
evaluating the stress and burden of caregivers of cancer patients, it was indicated that $82.3 \%$ of them had some level of stress ${ }^{(23)}$. Of these, $29 \%$ were in the exhaustion phase. At this stage, it is unlikely that the caregiver will be able to offer the necessary care to the cancer patient he/she cares for. An important predictor of stress is the issue of the sick child being the only child, a fact evidenced in this study, in which $32.3 \%$ have only one child, which can be an important predictor of stress ${ }^{(30)}$.

In this study, $75.8 \%$ of family caregivers indicated dissatisfaction with the Environment domain. This covers areas of physical security, protection, home environment, financial resources, leisure, transport, among others. This dissatisfaction was also observed in another study, indicating that caregivers suffer from precarious environmental and financial conditions, in addition to insufficient leisure and safety opportunities ${ }^{(31)}$. They also point out that the efforts required by parents to care for their children, as well as the financial and logistical problems that the treatment can create, expose them to considerable stress, with implications for their quality of life $\mathrm{e}^{(31)}$.

In seeking to understand the experience of family caregivers at the time of diagnosis and throughout cancer treatment, it was found that having a partner and more children can contribute to alleviating the physical and emotional burden and facilitating coping with stressful situations, due to emotional support and consequent reduction in the feeling of loneliness ${ }^{(2)}$. Having children can represent a support network that favors better coping with stressful situations. In the present study, the prevalence of the "most resilient" is higher when there are two or more children, but it is not significant $(p=0.532)$. Likewise, in the group of caregivers who have a child, the prevalence is higher for those classified as "less resilient". The support network is essential for coping with childhood cancer, as the task of caring is tiring and exhausting.

It was found that "resilient" parents tend to have less psychological distress ${ }^{(17)}$. This result is also present in another study, according to which, with a high level of resilience, parents are less likely to present mental disorders and behavioral disorders ${ }^{(24)}$. It was also identified that falls of just 1 point on a scale that measures resilience resources were associated with greater psychological distress and adaptability, concluding that parents of children with cancer have comparatively high rates of unfavorable outcomes, such as psychological distress, and that those with limited resilience resources may be at even greater risk ${ }^{(17)}$.

Families most likely to adapt are those that have a reduced number of causes of stress ${ }^{(17,20)}$. According to these studies, resilience is demonstrated by the ability to move forward and live better after cancer and is shaped by resources such as optimism, effectiveness, and the evolution of disease experiences, such as cumulative stress and personal growth. They also claim that supporting the psychosocial well-being of parents of pediatric cancer patients is an essential component of comprehensive patient care ${ }^{(17,20)}$.

Given the above, it is considered that the act of caring can generate overload, stress, and depressive symptoms, in addition to renouncing oneself to be able to exercise care. These feelings can affect the quality of life and health of family caregivers, and it is necessary to develop a support network aimed at prevention, rehabilitation and treatment, in order to improve the physical and mental health of family caregivers ${ }^{(4)}$.

\section{Study limitations}

The small number of participants, even with almost all family caregivers participating in the research, may be a limitation of the study, which suggests care in generalizing the findings. Another limitation is the impossibility of inferring the causality in the associations shown (temporal bias, characteristic of crosssectional studies).

\section{Contributions to the field of Nursing, Health or Public Policy}

Studies on resilience with family caregivers of children and adolescents hospitalized for cancer treatment are scarce. The findings of this study point to health changes, such as stress, propensity for MPDs and changes in the quality of life of family caregivers. Such evidence signals to the health team the need for an expansion of the look; that is, greater attention to family caregivers who are suffering, as they are also fundamental for the success of the treatment of childhood cancer.

New research, especially those with interventions, are essential to help diagnose and promote the health of family caregivers. The creation of "spaces for conversation" during hospitalization would enable the strengthening of caregivers who go through the same situation, being able to support themselves and know that they are not alone. Health professionals, especially nursing, as they are present daily during the patient's hospitalization, has the potential to observe, listen and, above all, intervene and transform experiences of suffering through a variety of actions and professional practices. Knowledge about resilience can support nursing professionals to alleviate suffering and boost the positive experiences of family caregivers, enabling them to provide individualized and comprehensive care.

\section{CONCLUSIONS}

It was found that family caregivers of children and adolescents undergoing cancer treatment were at a moderate level of resilience, with suspicion for MPDs and a high level of stress. In terms of quality of life, they were classified as satisfied in the Physical, Psychological and Social Relations domains and dissatisfied in the Environment domain.

As for the relationship between sociodemographic factors, leisure activity, work and resilience, no statistically significant difference was observed between the evaluated groups. However, resilience was negatively and significantly correlated with perceived stress and MPDs. That is, the higher the levels of resilience, the lower the scores for suspected MPDs and perceived stress. The correlation between resilience and the domains of General, Physical, Psychological, Social Relationship and Environment quality of life was positive, showing that the higher the level of resilience, the higher the QL and its domains.

\section{SUPPLEMENTARY MATERIAL}

This manuscript is the result of a master's thesis found in the UFSM repository, containing the access link: https://repositorio. ufsm.br/handle/1/17093 


\section{REFERENCES}

1. Instituto Nacional de Câncer José Alencar Gomes da Silva-INCA. Estimativa 2018: incidência de câncer no Brasil. Rio de Janeiro: INCA [Internet]. 2018 [cited 2018 Jun 18]. Available from: https://www.inca.gov.br/publicacoes/livros/estimativa-2018-incidencia-de-cancer-no-brasil

2. Fetsch CFM, Portella MP, Kirchner RM, Gomes JS, Bennetti ERR, Stumm F. Estratégias de coping entre familiares de pacientes oncológicos. Rev Bras Cancerol [Internet]. 2016 [cited 2018 Dec 11];62(1)17-25. Available from: http://www1.inca.gov.br/rbc/n_62/v01/pdf/04-artigo-estrategiasde-coping-entre-familiares-de-pacientes-oncologicos.pdf

3. Karkow MC, Perlini GNMO, Stamm B, Camponogara S, Terra MG, Viero V. Experience of families facing the revelation of the cancer diagnosis in one of its integrants. Rev Min Enferm [Internet]. 2015 [cited 2019 Oct 29];19(3):741-6. Available from: http://www.reme.org.br/exportarpdf/1036/v19n3a16.pdf

4. Medeiros EGMS, Leite RFB, Ramos DKR, Almeida LAL. Repercussões do câncer infantil no cotidiano do familiar cuidador. Rev Rene. 2014;15(2):233-9. https://doi.org/10.15253/2175-6783.2014000200007

5. Cordeiro LM. Fatores Associados à Qualidade de Vida Relacionada à Saúde e a resiliência de pacientes Oncológicos em Tratamento Quimioterápico e de seus Familiares [Dissertação]. São Carlos: Universidade Federal de São Carlos - UFSCar; 2018.

6. Connor KM, Davidson JRT. Development of a new resilience scale: the Connor-Davidson Resilience Scale (CD-RISC). Depress Anxiety [Internet]. 2003 [cited 2019 May 13];18(2):71-82. Available from: https://onlinelibrary.wiley.com/doi/epdf/10.1002/da.10113

7. Gomes GB Adaptação transcultural e propriedades psicométricas da versão brasileira do Adolescent Resilience Questionnaire (ARQ) [Tese]. Belo Horizonte: Universidade Federal de Minas Gerais - UFMG; 2015.

8. Zortéa J, Lazeri LL, Behling EB, Cruz LBA. Perfil nutricional e qualidade de vida de cuidadores de crianças e adolescentes com câncer. Clin Biomed Res. 2018;38(1):74-80. https://doi.org/10.4322/2357-9730.76438

9. Pedraza HMP, González GMC. Calidad de vida y soporte social em los cuidadores familiares de personas en tratamiento contra el câncer. Rev Univ Ind Santander Salud [Internet]. 2015 [cited 2018 Dec 13];47(2):125-36. Available from: https://pesquisa.bvsalud.org/portal/resource/pt/ lil-752918

10. Monteiro S, Lang CS. Acompanhamento psicológico ao cuidador familiar de paciente oncológio. Psicol Argum. 2015;33(83);483-95. https://doi. org/0.7213/psicol.argum.33.083.AO04

11. Costa MADJ, Agra G, Souza Neto VL, Silva BCO, Braz CSB, Mendonça AEO. Desvelando a experiência de mães de crianças com câncer. Rev Enferm Cent O Min. 2016;(6):2052-65. https://doi.org/10.19175/recom.v0i0.965

12. Jho, HJ, Choi JY, Kak KS, Chang YJ, Ahn EM, Park EJ, et al. Prevalence and associated factors of anxiety and depressive symptoms among bereaved family members of cancer patients in Korea. Medicine. 2016;95(22):1-8. https://doi.org/10.1097/MD.0000000000003716

13. Simpson GK, Dall'Armi L, Roydhouse JK, Forsther D, Daher M, Simpsn T, et al. Does resilience mediate carer distress after head and neck cancer? Cancer Nurs. 2015;38(6):30-6. https://doi.org/10.1097/NCC.0000000000000229

14. Santos APL, Rodrigues RTS. Resiliência em profissionais da saúde: percepção e realidade sobre autocuidado [Internet]. 2015 [cited 2018 Dec 16]. Available from: http://sobrare.com.br/Uploads/20150831_submeter_escola_da_sade.pdf

15. Gleeson A, Larkin P, Sullivan N. The impacto of meticicllin-resistant Staphylococus aureus on patients with advanced cancer and their family members: a qualitative study. Palliat Med. 2016;30(4):382-91. https://doi.org/10.1177/0269216315622125

16. Brolese DF, Lessa G, Santos JLG, Mendes JS, Cunha KS, Rodrigues J. Resilience of the health team in caring for people with mental disorders in a psychiatric hospital. Rev Esc Enferm. 2017;51:e03230. https://doi.org/10.1590/S1980-220X2016026003230

17. Rosenberg AR, Starks H, Jones B. "I know it when I see it": the complexities of measuring resilience among parents of children with cancer. Support Care Cancer [Internet]. 2014 [cited 2018 May 22];22(10):2661-68. Available from: https://link.springer.com/article/10.1007\%2 Fs00520-014-2249-5

18. Lopes VR, Martins MDF. Validação Fatorial da Escala de Resiliência de Connor-Davidson (Cd-Risc-10) para Brasileiros. Rev Psicol: Org Trab [internet]. 2011 [cited 2018 Oct 10];11(2):36-50. Available from: http://pepsic.bvsalud.org/scielo.php?script=sci_arttext\&pid $=$ S1984-66572011000200004

19. Mari JJ, Williams P. Validity study of a Psychiatric Screening Questionnaire (SRQ-20) in primary care in city of São Paulo. British Journal of Psychology [Internet]. 1986 [cited 2018 Mar 17];148(1):23-26. Available from: https://www.cambridge.org/core/journals/the-british-journal-ofpsychiatry/article/validity-study-of-a-psychiatric-screening-questionnaire-srq20-in-primary-care-in-the-city-of-sao-paulo/94BFEFAF754ADABF 52A244AEA28BC436

20. Fleck MPA, Louzada S, Xavier M, Vieira G, Pinzon V, Chachamovich E, et al. Aplicação da versão em português do instrument de avaliação da qualidade de vida "WHOQOL-bref". R Saúde Pública[Internet]. 2000 [cited 2018 Jun 23];34(2):178-83. Available from: https://www.researchgate. net/publication/26344585_Aplicacao_da_versao_em_portugues_do_instrumento_abreviado_de_avaliacao_da_qualidade_de_vida_ WHOQOL-BREF

21. Luft CDB, Sanches SO, Mazo GZ, Andrade A. Versão brasileira da Escala de Estresse Percebido: tradução e validação para idosos. Rev Saúde Pública. 2007;41(4):606-15. Available from: https://doi.org/10.1590/S0034-89102007000400015 
22. Dancey C, Reidy J. Estatística sem matemática para psicologia: usando SPSS para Windows. Porto Alegre: Artmed; 2006.608 p.

23. Maronesi LC, Silva NR, Cantu SO, Santos AR. Indicadores de estresse e sobrecarga em cuidadores formais e informais de pacientes oncológicos. Estud Pesqui Psicol. 2014;14(3):877-92. https://doi.org/10.12957/epp.2014.13889

24. Ye ZJ, Qiu HZ, Li PF, Chen P, Liang MZ, Yu YL, et al. Validation and application of the Chinese version of the 10-item Connor-Davidson Resilience Scale (CD-RISC-10) among of children with cancer diagnosis. Eur J Oncol Nurs. 2017;27:36-44. https://doi.org/10.1016/j.ejon.2017.01.004

25. Rodrigues FMS, Vulczak VLS, Alencar CF, Santos, LSC, Nascimento LC. Concepções dos pais acerca da doença oncológica e do tratamento quimioterápico de seus filhos. Rev Enferm UFSM. 2020;10;1-17. https://doi.org/10.5902/2179769235898

26. Figueiredo T, Silva AP, Silva RMR, Silva JJ, Silva CSO, Alcântara DDF, et al. Como posso ajudar? sentimentos e experiências do familiar cuidador de pacientes oncológicos. ABCS Health Sci. 2017;42(1):34-9. https://doi.org/10.7322/abcshs.v42i1.947

27. Almico T, Faro A. Enfrentamento de cuidadores de crianças com câncer em processo de quimioterapia. Psicol Saúde Doenças. 2014;15(3):72337. https://doi.org/10.15309/14psd150313

28. Soares AR, Sabião R, Ferreira G. Psicologia, religião e espiritualidade. Psicodebate [Internet]. 2019 [cited 2018 Jun 23];5(Suppl.1):43-1. Available from: http://psicodebate.dpgpsifpm.com.br/index.php/periodico/article/view/V5S1A2

29. Pardo XM, Cárdenas SJ, Venegas JM. Variables que predicen la aparición de sobrecarga en cuidadores primarios informales de niños con câncer. Psicooncol. 2015;12(1):67-86. https://doi.org/10.5209/rev_PSIC.2015.v12.n1.48905

30. Sulkers E, Tissing WJE, Brinksma A, Roodbol PF, Kamps WA, Stewart RE, et al. Providing care to a child with cancer: a longitudinal study on the course, predictors, and impact of caregiving stress during the first year after diagnosis. Psychooncology. 2015;24:318-24. https://doi. org/10.1002/pon.3652

31. Rocha RS, Pinheiro LP, Oriá MOB, Xineses LB, Pinheiro AK, Aquino PDS. Determinantes da saúde e qualidade de vida de cuidadores de crianças com câncer. Rev Gaúcha Enferm. 2016;37(3):1-6. https://doi.org/10.1590/1983-1447.2016.03.57954 